\title{
Imagining Indigenality in Romance and Fantasy Fiction for Children
}

\author{
Brooke Collins-Gearing
}

$\mathrm{T}$ his essay explores how non-Indigenous authors of children's romance and fantasy narratives have positioned themselves as authorities on Indigenous peoples and the Dreaming, often authorising their own concepts of the Dreaming and of Indigenous history to inform and 'indigenise' non-Indigenous child readers. Throughout this discussion I will draw on examples from both romance and fantasy narratives, because since the nineteenth century these genres have operated in similar ways to construct Indigenality for the understanding of non-Indigenous children through the appropriation of Indigenous concepts, images and symbols. ${ }^{1}$ Whereas fantasy can be completely separated from the 'believable', romance must retain some elements of it. In romance stories the restrictions of the political, economic and historical world are completely removed. They resemble 'real' life on the surface but offer solutions that can only be achieved by eliminating the encumbrances of social reality (Jameson pass 1975). Analysis of the connection of fantasy and romance to colonialism is necessary in order to understand how these genres have fostered stereotypes of the Aborigine, including those in contemporary Australian children's fiction. I will focus on two texts from the late nineteenth century, Arthur Ferres's My Centennial Gift; or, Australian Stories for Children (1887) and Mary Anne Fitzgerald's King Bungaree's Pyalla and Stories Illustrative of Manners and Customs that Prevailed Among Australian Aborigines (1891), and a selection of twentieth-century texts which draw upon the conventions of romance and fantasy: Frank Dalby Davison's Children of the Dark People (1936); Ann E. Wells's Arnhem Land trilogy, Tales from Arnhem Land (1959), Rain in Arnhem Land (1961) and Skies of Arnhem Land (1964); and, from the late twentieth century, Poppy Boon's The Black Crystal (1993).

Fantasy and romance narratives written for children assume the familiarity of the reader both with the genre and also with the social reality of Western society: for example, that an inanimate object can speak in a fantasy story or that amazing events are plausible in romance narratives. Therefore, representations of Indigenous cultures and people in fantasy and romance narratives are based on narrative practices which are informed by Western society and its values. Non-Indigenous children are positioned as readers through depictions of fantastic Indigenous characters and social discourses about race and social hierarchy. Most importantly, fantasy and romance genres enable non-Indigenous authors to propagate the idea of a dying race and/or a people in a timeless, remote past. Consequently, in romance and fantasy genres, Indigenous cultures and peoples are secondary to non-Indigenous ideas of the natural, the primitive, the inexplicable and the mystical. Authors of romance and fantasy literature imagine Indigenality as 'traditional' when they cannot account for the empirical reality of Indigenous society. Imagining Indigenality removes the problems of invasion, genocide and assimilation. For such authors, fantasy and romance genres disregard or repudiate aspects of Indigenous cultures that do not conform to their purposes - or in Ann Swinfen's words, to the author's 'own scheme of morality' and her/his own 'political and social order' (1984, p.231). Swinfen argues that fantasy reveals the social order, which in the texts I discuss is based on colonial attitudes. In the fantasy and romance literature of the nineteenth century - which influenced fantasy literature of the twentieth century - the image of the Aborigine becomes a symbol dissociated from the realities of dispossession and poverty as well as of urban life.

The nineteenth-century 'Australian fairy', the 'English-speaking koala' and the 'Aborigine'

Nineteenth-century fantasy and romance narratives invented characters that could conveniently be termed 'Aborigines' for the purposes of the story. English and European literary traditions created the basis for folk and fairy stories in Australia that included not only native fauna but fantastic Indigenous characters. Early in Australia's colonial history, non-Indigenous authors realised the difficulty of adapting English literary characters to the Australian landscape and fauna because figures such as goblins, fairies and pixies did not fulfil attempts to create a unique Australian setting. Arthur Ferres, in his foreword to My Centennial Gift, published after one hundred years of white invasion, stated:

These stories ... were written for those to whom they are now dedicated, and in the hope that they might do some little good among country children ... their aim [is] to reach the hearts and heads of young Australians by appealing to the surroundings 
of their everyday lives. We cannot live for ever on the fairy and goblin stories of the home country, and, indeed, it is very questionable if an Australian child has any idea of what a fairy or a giant is ... It has struck the writer in the course of his rather extensive bush experience among children, how very little in the way of juvenile literature there is which an Australian child can sympathise with and understand.

(Ferres 1887, preface)

In entertaining the idea of an 'Australian' child, and what an Australian child needed and wanted, Ferres ignored the culture and identity of Indigenous children. By populating the Australian bush with more 'believable' magical creatures, the non-Indigenous author transformed the English fairy into an English-speaking native animal, but retained other literary conventions of the fantasy genre. There was little deviation from the tried and tested English fantasy formulae: the characters may have looked like native Australian animals, but they behaved very much like English characters. By inserting Australian figures into an English genre, fantasy stories enabled authors to promote Western conventions and ideologies in what were ostensibly fairy stories with Australian backgrounds and settings.

Ferres's stories include 'The Wallabies' Ball', which concerns the killing of the last Dingo, represented as the principal enemy of Australian animals. His Highness, the Prince of Wallabyland, is informed that the Dingo is dead and a magnificent ball is arranged. At the ball, six savage dingoes arrive and kill many of the guests. The characters, both animal and human, are Anglicised: they speak standard English, live in constructed homes and implement English social practices, such as court cases and balls. The text projects a structured social and political order. The Australian element of the stories is their setting and veiled references to the Australian black. In 'The Quack Doctor', a bird doctor from Africa arrives and charms most of the other birds except for the 'goburra' (kookaburra). The goburra speaks, supposedly, like a 'blackfellow': 'Him bery big pella-too muchee' (1887, p. 50), while all the other characters speak standard or 'proper' English. In 'The Beetle and the Cricket', the final moral that the story pronounces is: 'There are many poor little black crickets in the world who sigh to be fine beetles; but you will, I'm sure, think with me that they are better off as they are' (1887, p.152). The use of racialised anthropomorphic animal characters not only reinforces non-Indigenous social and political structures but also serves the purpose of teaching non-Indigenous child readers about racial difference and the idea of racialised social hierarchies.

White child readers occupied a subject-position in relation to the narrative that enabled them to objectify Indigenous people as subordinates. The desire to interest and entertain (white) Australian child readers through stories involving distinctively Australian creatures conformed to the dominant ideologies of the time. It also foreshadowed the purpose of non-Indigenous representations of Indigenous Dreaming in the legend book genre. One purpose shared by the legend book and the fantasy story was to preserve information about a 'fast-dying race' in order to offer white Australia a foundation on which to build a unique cultural identity. In many nineteenth-century and early twentieth-century fantasy texts, authors state, in prefaces or forewords, that they want to teach white children more about Australia and its creatures to build a sense of belonging and identity, and to preserve information before any of the creatures become extinct. The preservation of native animals established a literary purpose in children's books that was later replaced with the intention of preserving remnants of the dying Indigenous race. The attempted genocide of Indigenous peoples and cultures was implied but not explicitly stated in children's literature.

English connotations of primitiveness and the primal were attached to the Australian native, while Australian animal characters whose speech and behaviour was modelled on English conventions duplicated the non-Indigenous presence in the land. In the absence of non-Indigenous cultural landmarks, the strange antipodean flora and fauna became the symbols of Australia's uniqueness. Often included in these representations of a mysterious and even mystical Australian bush were images of Indigenous peoples. A kangaroo or koala could be more easily depicted speaking and behaving in an English manner-and often wearing English clothes - than the 'Australian Aborigine'. The Australian animal was anthropomorphised into a recognisable conventional English image: the white rabbit simply became a platypus. Anthropomorphised animal characters could simulate fairies or other figures from English folklore 
but, in contrast, the image of the Aborigine was invented for the purposes of these narratives and built on non-Indigenous perceptions.

Images of Indigenality were commonly used as background material that served the purpose of populating the Australian countryside with recognisable fantasy figures. For example, an image of Indigenality in Ethel Pedley's Dot and the Kangaroo (1899), a 'classic' children's fantasy, is a peculiar part of the setting viewed by Dot:

Dot nearly screamed with fright at the sight. She had thought she would see a few black folk, not a crowd of such terrible people as she beheld. They did not look like human beings at all, but like dreadful demons; they were so wicked and ugly in appearance. The men who were dancing were without clothes, but their black bodies were painted with red and white stripes and bits of down and feathers were stuck on their skin. Some had only white stripes over the places where their bones were, which made them look like skeletons flitting before the fire ... The tribe people were squatting in rows on the ground, beating boomerangs and spears together, or striking bags of skin with sticks, to make an accompaniment to the wailing song they sang ... yelling the words of the corroboree song, as the painted figures, like fiends and skeletons, danced before the row of fires.

(Pedley 1899, pp. 69-70)

Such representations that alluded to corroborees signified exoticism but were conventional tropes in fantasy texts, unlike other Indigenous practices, such as educating children or simply going about daily chores, which were rarely represented. The inclusion of Aboriginal characters as exotic figures, villains and demons effects the Westernization of the fantasy land, which is inhabited primarily by animals and humans who speak English and wear clothes like Anglo-Australians.

One of the first examples of a non-Indigenous attempt to create a fantastical Australian environment from an Aboriginal foundation, instead of an English one, was Mary A. Fitzgerald's King Bungaree's Pyalla and Stories Illustrative of Manners and Customs that Prevailed Among Australian Aborigines (1891). Fitzgerald's book can be evaluated as a precursor to the translation works of such people as Kate Langloh Parker, who published her Australian Legendary Tales in 1896. Fitzgerald wrote her translations using the conventions of fantasy literature and inserting them into fairy tale narratives. Fitzgerald received most of her information from a 'Black King' and acknowledged this in her preface and introduction. Unlike many non-Indigenous authors of Australian children's literature before and after her, Fitzgerald tried to interpret Indigenality based on her knowledge of Aboriginal Australia, instead of completely fabricating her own interpretations. Just as many subsequent authors attempted to preserve some knowledge of the Aborigine, Fitzgerald wanted to save information concerning a 'dying race':

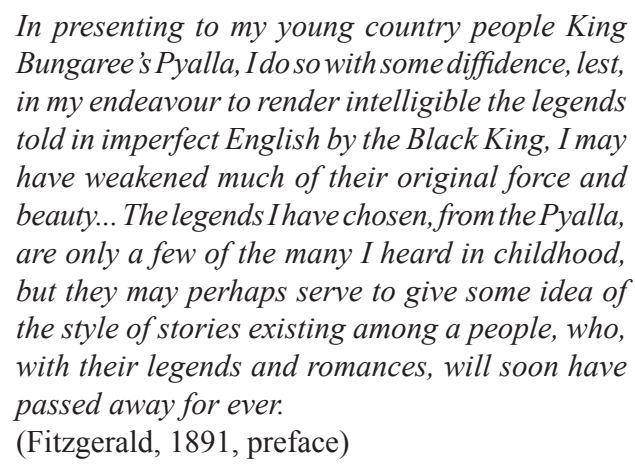

In her interpretation of King Bungaree's stories, the author often refers to the Aboriginal peoples as 'Koree' and recognises that the land belonged to them before the colonisers came. In standard English, with a glossary of Aboriginal words included, Fitzgerald tells the stories of 'how things became'. Thus, through a narrative using the local Aboriginal names of birds and animals, the reader learns about why the Kukuburra laughs, how the Tewinga (Bower-bird) learned to build its bowers, and about the habits of other native Australian animals. Also included in the book are stories about Aboriginal characters presented as 'legends', but they are narrated in a somewhat different manner. They are concerned with events that happened to people - mostly in the context of relations between black and white. In 'Owingee' the reader learns how the colonisers interact with the 'aborigines', offering employment, food, and clothes. When Mrs Peverill, a farmer's wife, offers Owingee - the Black king's wife — a gift of clothes, 
it is made clear that though they share in common a liking for dresses, their positions in life are very different: the dresses were 'equally dear to the heart of the high-born lady and her lowly sister the blackwoman' (1891, pp.46-47). Ideas of social and political hierarchy are reinforced for non-Indigenous child readers. Other stories by Fitzgerald depict how white children 'train' a little Aboriginal girl to sing songs in English; the rescue of a white child by a 'handsome young black'; and a story for white children on Christmas eve about a faithful Aboriginal servant.

Whether or not the actions of Aborigines are worth narrating depends, in Fitzgerald's text, on the involvement of non-Indigenous children. King Bungaree tells of his knowledge of the landscape only because non-Indigenous children have requested it and, therefore, can convey it to later (white) generations. The fantasy narrative records Indigenality as belonging to a past time that is slowly vanishing, a construction which presents the idea that a harmonious, but brief, relationship existed in the early days of colonization between colonists and Indigenous peoples. In this way Fitzgerald's fantasy narratives about black/white relationships absolve non-Indigenous child readers from the memory and knowledge of policies and practices of genocide and assimilation. It also removes the difficulty of having to acknowledge or accommodate Indigenous peoples of Fitzgerald's time, whether 'traditional', remote, 'assimilated' or urban.

\section{Twentieth Century Non-Indigenous Imagining of Indigenous Culture}

Representations of contemporary Aborigines rarely appeared in children's romance fiction, in either nineteenth or early twentieth-century texts. By representing Indigenality as a component of an Australian past, non-Indigenous authors could avoid contemporary issues and thus create an image of the blackfellow that more easily and successfully fulfilled the story's purpose. Tim Fulford and Peter J. Kitson argue that the conquest of land was only one part of imperial control. The other was the enforcement of ideological and cultural systems (1998, p.3). When non-Indigenous authors used Indigenous peoples as subject matter for their children's stories, Indigenality was manipulated to serve dominant ideologies and expectations. Ideas of Indigenality sometimes created a dichotomous idea of an arcadian society differentiated from Western capitalist society. Very little remained of actual Indigenous perspectives or cultures in romantic narratives.

Twentieth-century fantasy and romance narratives located Indigenous peoples in the past, allowing non-Indigenous Australia to become the authority on Indigenous culture. European and Anglo-Celtic fairy tales were replaced with 'folklore' about Indigenality. The construction of the Australian bush as a fantasy place meant that non-Indigenous beliefs shaped the use and representation of 'the Aborigine'. The idea of the 'traditional'Aborigine symbolised for many non-Indigenous authors an arcadian, idyllic landscape: the Aborigine was perceived, as Jan Kociumbas recognises, in both social and literary contexts, as 'a lower form of civilisation ... having little more to their lifestyle than a day-to-day concern with survival' (1988, p.254). Such depictions relied on the Aborigine remaining static, as representations of a dynamic Indigenality would need to address the impact of invasion and colonisation. Twentieth century romance and fantasy narratives dealt with these effects by teaching non-Indigenous child readers only about the demise of Indigenous peoples.

After decades of representing the Australian black as a savage, inferior, depraved 'race', the idea of the Aborigine as pastoral and unspoilt emerged during the twentieth century. Non-Indigenous authors incorporated into their fantasy and romance stories the idea of a simple, pastoral, unencumbered lifestyle. Such depictions not only simplified and diminished Indigenous philosophies but often misappropriated Indigenous knowledge and practices. Whether the protagonists were non-Indigenous Australians coming into contact with a 'traditional' Aboriginal person or place, or Aboriginal characters in a pre-contact community, such representations of Indigenality revealed more about nonIndigenous ideologies and values than Indigenous cultural beliefs. Gail Ching-Liang Low, in her discussion of the boy's adventure story (a sub-genre of romance adventure stories) states that its representation of 'feelings of lost innocence and nostalgia' typify 'the poetics of Empire. It achieves the twin tasks of disowning culpability for the destruction of indigenous cultures, and of producing a gendered [, racial] and ... infantilised notion of culture, central to the imperialist mythopoetics of the [adventure romance] story' (1996, p.43). 
Problematic issues such as language, cultural knowledge and identity - and accurate local or regional accounts - could be circumvented, or just simply ignored, within the romance genre. Cultural translations and contemporary social and political injustices remained outside the boundaries of the image of an idyllic, simple Indigenous lifestyle. This construction of Indigenality manipulated the image of the Aborigine so that the 'Other' could be described and understood by non-Indigenous child readers and their culture. In children's romance fiction, the image of the Aborigine became more than just an 'idea', it became 'usable fiction'. Low argues that: 'The colonial fabula stitches together white mythology and black history, but this act of dispossession mirrors the dispossession of colonialism and the ease with which it colonises the space of African [or Indigenous] significations with its own fantasies' (1996, p.100).

Such acts of dispossession are often apparent in Australian children's romance literature. In his prologue to Children of the Dark People, Frank Dalby Davison reveals white Australia's reliance on an imagined Aboriginal existence to create an Australian mythology:

This story of two children of the dark people who once roamed the Australian bush, who were sofew and who have now almost passed away, is not about any special part of the bush; it might have happened in any place where grass still grows and gum-trees stand. And, although the dark people have mostly gone, the Spirits of the Bush are still with us; the Spirits of the Billabong, of the Mountain Gullies and of the Plains. Grandfather Gumtree is still to be found, if you look for him, by river, creek and mountainside; and Old Mr Bunyip who looks after the wild creatures of the bush and the beasts of the paddocks, who shows the birds their green places of hiding, and who draws the rain clouds to where the earth lies thirsty, still passes through the land on his many errands.

(Davison, 1936, prologue)

Davison clearly states his belief that the 'dark people' will soon cease to exist, but in their place will be 'white' creations, these 'spirits of the bush' produced by non-Indigenous authors' narratives about Aboriginal culture. A fabricated white version of Aboriginality forms the basis of the narrative. Davison's story tells about the adventures of an Aboriginal boy and his sister and the encounters they have in the bush with imaginary creatures - the supposed 'spirits of the bush'. The creatures strongly resemble those from English literary traditions. Davison's creations include non-Indigenous characters, such as the Spirit of the Billabong, the Singer of the Dawn, the very Anglo-Celtic Mickatharra, the Brumbie's Boy (a boy who lives with the brumbies) and Old Mr Bunyip-an old man spirit who looks after the land and everybody in it. Davison's narrative is an allegory of both colonisation and dispossession. In 'A Note for Guardians' the author states:

This tale is intended for readers of about ten to fourteen years. It deals with the adventures of two aboriginal children who became lost and found their way home again. Though it embodies considerable bush and darkfolk lore it makes no pretence to being aboriginal legend-except to the extent that a story of lost children probably belongs to all races, and perhaps had its origins in the treetops with apprehensive parent monkeys. Jackadgery and Nimmitybel are current white-fellow adaptations of native place-names ... The introduction of brumbies into the primitive Australian scene has been pointed out to me as an anachronism. I committed it unthinkingly, being moved by a knowledge of the extent to which imported animals gone wild-donkeys, camels, buffaloes, cattle, horses - have found so friendly a home in the outback bush that their original absence seems a little unnatural. On reflection, I have decided to stand by my story. Youthful sticklers for the facts of natural history - if any such exist - can substitute emus for brumbies in the chapter where the latter are introduced; or, alternatively, it might be taken that mystory falls - with easyconvenience - in the very early years following white settlement.

(Davison 1936)

Davison situates his romance narrative not only to remove all non-Indigenous social encumbrances, but also to allow him to avoid acknowledging any Indigenous ownership of information. The author's note reveals - in Frederic Jameson's terms - a fictional solution to a historical contradiction that it represents (1981, p81). Although the 
author disclaims an intention to have his text masquerade as 'aboriginal legend', his work reveals literature's part in the imperial regime that produced and enforced ideological and cultural systems (Fulford and Kitson, 1998, p.3). Like 'white-fellow adaptations of place-names', Davison's fantasy narrative appropriates and interprets both natural history and Indigenous culture. Children of the DarkPeople is completely framed by non-Indigenous ideas, purposes and expectations. A verse by Henry Lawson about fairies and bush-lost babies is included at the beginning of the narrative, while the Epilogue reinforces the arrival and occupation of white people in the land. The author finishes the story by informing the child reader that the white men eventually appeared in all directions with their crops, their tools, their cattle, sheep and horses, and that, ultimately, Old Mr Bunyip 'in his nobility... took them also into his care' (1936, p. 175). A romance narrative of 'traditional' Indigenous culture offers an origin for both white child readers and the colonisers who replace the original inhabitants of the land. Children of the Dark People is an example of Australian children's literature that includes representations of Indigenality to naturalise the impact of white invasion. Aboriginal existence becomes merely a distant past existence that preceded non-Indigenous Australian society. In the romance genre, ideas of the Aborigine arise from and support imperial power and sovereignty, and include false solutions and happy endings.

Australian children's fiction, minimalising the physical, psychological and spiritual displacement that Indigenous peoples of Australia experienced, could express the colonisers' idea of nature, their criticism of capitalism, their need for a history, their desire to mark boundaries, their positing of the 'Other'. They could moralise, they could fabricate, they could entertain, and they could control. Ironically, such texts subtly emphasise the impact of Indigenous Australia on white Australia. Fantasy and romance allowed non-Indigenous authors to avoid explaining what they did not know or could not understand but the nonIndigenous fascination with Indigenous images reveals the impact on white Australia. Homi Bhabha's theory of colonial discourse explains the instability of the colonisers' appearance of authority:

It is not that the voice of authority is at a loss for words. It is, rather, that the colonial discourse has reached that point when, faced with the hybridity of its objects, the presence of power is revealed as something other than what its rules of recognition assert. If the effect of colonial power is seen to be the protection of hybridization rather than the noisy command of colonialist authority or the silent repression of native traditions, then an important change of perspective occurs. It reveals the ambivalence at the source of traditional discourses on authority and enables a form of subversion, founded on that uncertainty, that turns the discursive conditions of dominance into the grounds of intervention.

(Bhabha 1994, p. 112)

The authority attributed to scientific knowledge is often apparent in the texts I discuss, but the 'Other' becomes more complex than simple racist stereotypes or fantasies of difference. The non-Indigenous idea of the Aborigine in Australian children's literature often reveals the ambivalence of difference that Bhabha discusses.

The conventions of fantasy and romance genres enabled non-Indigenous authors to use the image of the Aborigine as the central protagonist. Romance narratives represented fabricated aspects of Indigenous life as 'traditional'. Aboriginal characters, as a result, could be naked, retain their hunting and gathering practices, but speak English. Non-Indigenous authors of fantasy and romance children's literature presumed they did not require either accurate knowledge of Indigenous culture or the permission of Indigenous people to represent the 'mystical truth' of Indigenality. Not only were Indigenous lands and landmarks appropriated by the colonisers, 'but children's literature contributed to cultural appropriation and degradation.' Questions about the ownership of cultural property remain a problematic issue in late twentieth-century children's literature.

Non-Indigenous child readers and the non-Indigenous characters learn about the land through Aboriginal characters in romance and fantasy narratives. The white characters become somewhat 'indigenised' so they can live on what was once an alien land. This is one purpose of the narrative: to give non-Indigenous readers a relationship with an environment invested with 'mystical' meanings. This 
purpose is enhanced by the idea that Aborigines are a dying race and that their place in the land needs to be filled. As Goldie states:

Regardless of questions such as that raised by Fanon about the validity of indigene mysticism within the indigenous cultures, indigene mysticism in the white text is devalued as it is emphasised. Throughout these literatures, the image of the indigene as guardian spirit proves unable to guard the spirit of the indigenous peoples from the acquisitory powers of the indigenising text. Or, to put it in the terms of a blunt analogy, if the rabbit's foot were lucky it would still be on the rabbit.

(1989, pp.146-147)

Romance and fantasy children's fiction tried to create the 'traditional' Aborigine while non-Indigenous Australian society tried to annihilate, assimilate or suppress any traces of Indigenous peoples and cultures.

\section{Positioning the 'past Aborigine' in the present}

Concepts of race are dependent on the social, cultural and political climate of the time in which they figure. For most of the twentieth century, white Australian policies ignored Indigenous Australians and the contemporary Aborigine lived under stringent assimilation policies. Yet non-Indigenous authors focussed on-or used-an idealised pre-contact image of Indigenality, which was free from the control and injustices of non-Indigenous society and politics. 'Race' helped to define and position the presence of Indigenality in romance and fantasy fiction. After Indigenous rights became more widely recognised and Indigenous peoples became more prominent in mainstream Australian society, the concept of 'race' in fantasy and romance fiction altered.

The attention of white child readers is directed towards relevant social concerns instead of a secondary idyllic reality in Poppy Boon's fantasy novel The Black Crystal (1993), which incorporates many traditional romance and fantasy conventions into the novel's contemporary setting. Boon appropriates ideas about Indigenous customs and concepts to portray the mystical journey of a non-Indigenous girl who becomes indigenised in much the same way that early colonial stories used the idea of a white man who lives with the 'natives' and is initiated as a white Aborigine. To connect an Aboriginal past and the contemporary non-Indigenous character, the narrative alludes briefly to reincarnation. Boon's ideological messages are obvious throughout the narrative, especially when they focus on the interaction between the black and white communities:

while their small community was generally shared peacefully by Aboriginal and non-Aboriginal people alike, there was still a sense of caution when it came to forming friendships between the two. Emma [the protagonist] had always been aware of it even though she didn't understand it. Lindy [her mother] had told her that many Australians still felt prejudiced towards Aboriginal people, while others felt so embarrassed about what had happened to them since white settlement, that they were hesitant about offering friendship for fear of rejection. Lindy had also explained that Aboriginal peoplewere likewise cautious, because of the way white people had already taken so much from them in the past, and in a lot of cases were still taking.

(1993, p.15)

Prejudice based on skin colour is also mentioned, and the greed of one race that almost destroys another, but both are described by the narrator as 'complex issues' which cannot be explained easily.

The story tries to incorporate Indigenous knowledge through the experiences of a non-Indigenous character and the relationships between black and white peoples who reconnect with 'Mother Earth'. The white female protagonist dreams about an Aboriginal woman and hears distant voices. She meets Warlawurru, a Pitjantjatjara boy, and together they embark on a mission to retrieve the black crystal, keeping it from evil hands. Indigenality is included to strengthen the non-Indigenous connection with the land. And, as Bradford notes, it is also 'plundered, dismembered and inserted into a narrative that positions its readers to see Aboriginality as a repository of goods to be used in Emma's search for self-realisation' (2001, p.150). Warlawurru's grandmother Pirntirriminyma, the Aboriginal woman about whom Emma dreams, tells Emma that all Australians, regardless of colour, have a connection 
with the Ancestral Beings. She tells Emma: 'You child wear a white coat, but to those who can see it does not disguise who you are. You, and others like you who are being called by the Ancestral Beings at this time, form the bridge between those who share your skin colour and the Ancient Ones. It is a bridge made up of many colours. A Rainbow Bridge. A few make the bridge so that many may cross over' (Boon, 1993, pp. 58-59). The continual emphasis on skin colour undermines Boon's message that it is not important.

Boon tries to challenge ideas and stereotypes about Aborigines, but her attempts at disrupting them often collapse. Emma confronts certain non-Indigenous expectations of Aboriginea - such as their language, the way they live and their traditional practices. When Warlawurru first meets Emma, he teases her with the way he speaks:

\begin{abstract}
'But plenty-big old man croc further downstream. He like white girl like you. Make good tucker.' Emma giggled. 'You sound just like they make most Aboriginal people sound on the TV or in the movies.'
\end{abstract}

'I know, 'Warlawurru grinned wickedly. 'I think
they like to forget that most of us speak English like
everyone else, or if we don't, then we 're fluent in
our own language. Still, best not to get me started
on that topic. It makes me angry.'
(Boon 1993, p.39)

When Boon describes Warlawurru, however, Emma sees that 'the face looking back at her was Aboriginal' (1993, p.33). The narrative, in this manner, returns to blackness as Warlawurru's defining characteristic. Not only does Warlawurru know how to track, "he also knew how to "read" the wilderness and survive without modern conveniences. Even if it did mean having to eat possum' (1993, p.22). The idea of the contemporary Aborigine in Boon's narrative relies heavily on 'traditional' images of blackness and a past, natural state.

Emma's relationship with these Indigenous characters and her connection with the past allows her to be initiated by the Aboriginal women of the community. At first she is fearful of the initiation ceremony, remembering what she has read aboutAboriginal people in history textbooks. After the ceremony, though, 'It was as if she understood in some unspoken way her reclamation had renewed her pledge to serve the Mother Earth and the Ancient Ones, and the knowledge filled her with a powerful sense of belonging' (1993, p.96). Boon encourages her non-Indigenous child readers to become more cognisant of Indigenous Australia — or, at least with an idea of Indigenous Australian history - so that their own sense of place is enhanced. The Black Crystal tries, through the use of fantasy conventions, to represent Indigenality and an Indigenous presence in contemporary Australian society. However, the text re-uses colonial tropes and representations of Aborigines that were popular in nineteenth-century children's literature.

It is noticeable that Ann E. Wells's Arnhem Land trilogy, written thirty years before Boon's narrative and at a time when strongly assimilationist policies prevailed, relies less than Boon's on colonial tropes of Aboriginality. Wells presents Indigenous protagonists in a contemporary setting, basing her representation of Indigenality on nonIndigenous literary ideas, but incorporating a respect for Indigenous philosophy. Her preface to Tales From Arnhem Land (1959) reveals an attempted variation on traditional non-Indigenous interpretations of Indigenality:

Milingimbi, one of the Crocodile Islands, lies off the coast of Arnhem Land, not far from Cape Stewart ... Here, on part of the Great Aboriginal Reserve of Arnhem Land, are the descendants of the first Australians, whose legends and lore survive and are preserved among the yulnu. These three tales are built round legends from the folk lore of the coastal Aborigines of Northern Australia. Theytell how the Aborigines account for their first coming to Australia, how the Dreamtime heroes taught them the way to live, and how the first tribesmen learnt the use of firesticks. They account for the making of the first canoe and the coming of the dingo. They reveal how the Aborigines credit naturalfeatures, like water-holes and rivers, to the activities of creatures of the Dreamtime. The tales containing the legends reflect the modern lives of Aboriginal children in the North, with fantasy and fact intermingled as they are in the minds of the people. As told to Ann Wells of Milingimbi by the Wurrungu, their stories are instinct with the poetry 
of primitive beliefs.

(Wells, 1959, preface)

Wells does not position non-Indigenous child readers as cultural keepers of Indigenous knowledge. It is recognised that Indigenous people continue to preserve Indigenous information. However, the preface's explanation of Indigenality relies on typological time: modern Aboriginal children are differentiated from the primitiveness of their traditional beliefs.

Wells's narratives follow the experiences of three Aboriginal children: experiences that mostly involve 'fantastical' trips to a 'dreamland'. When Wurrungu, 'the Old One', asks the Aboriginal children to explain about school, what follows resembles a description of whiteness. Wells's implicit message is that the white way is not necessarily superior to 'traditional' Indigenous ways, but that by learning both 'you have the power to choose; to do or not to do, as you wish' (1959, pp.18-19). Wells combines Indigenous and English words and Indigenous legends and non-Indigenous beliefs, to provide the reader with an image of Indigenality that does not involve Aboriginality being problematic - especially in regard to child characters. The Old One, a Dreaming spirit, always has a final message for the children that reveals non-Indigenous influences on ideas of Indigenality: 'It is good to find that the new ways do not spoil the old, and very good to find that my tribe still remember that the young must be courteous to the old and the strong to the weak ... Never be ashamed inside your hearts of your own people, or of those who have lived before you. Unknowing they may have been; but do not forget, they were the first people this land of ours knew. Always be glad you belong to our tribe' (1959, pp.29-30). Alongside the acknowledgment of Indigenous occupation of land and of pride in Indigenous heritage, it is implied that being Indigenous means shame and a belief that older Indigenous people were ignorant.

In Wells's next instalment, Rain in Arnhem Land, her use and interpretation of the Dreaming becomes less fantastical. Recognising her Indigenous sources and the traditional education of Indigenous children, Wells includes five more Indigenous legends and builds on the progress of her characters as their education and understanding increases. Unfortunately, the non-Indigenous framework of Wells's narrative is reinforced by the blurb on the inside of the front cover. Wells explains in her preface the relationship between certain animals, birds, insects and 'aboriginal' people. The blurb, however, introduces the idea of talking animals as purely fantastic:

It would not seem unusual to an aboriginal that
a wallaby or a pelican should speak, for all the
people of these tribes believe that certain animals
are their relations. And so it is not out of place
here for the great folk legends to be told by the
creatures of the bush andsea. Through these simple
poetic tales about life in the long ago Dreamtime,
the children come to understand their people's
explanations for naturalfeatures and happenings.
The legends are set in the framework of everyday
life on the Crocodile Islands off the coast of
Arnhem Land. The story is rich in detail about
a remarkable people - how they live, how they
find their food, how the children play, how they
see magic and fantasy simply as another part of
nature. Australian children will find here a story
that brings to life a part of their homeland and
heritage. Others will discover a new world, filled
with beauty and adventure.
(Wells 1961)

The blurb reinforces the idea that both 'traditional' Indigenous stories and children's literature are 'simple'. It differentiates between 'Australian children' and 'others' without defining either. Could 'Australian children' refer to both Indigenous and non-Indigenous readers? The final book of Wells's Arnhem Land Series, Skies of Arnhem Land (1964), emphasises more than the previous two narratives the belief that the Dreaming is a childlike fantasy. By the end of the third book, the implicit message is that the children have reached an age where they can no longer be a part of, or even remember being a part of, their experiences in the 'Dreamland'. Wells's attempt to represent Indigenality is restricted by non-Indigenous ideas of the child and the English language, that is, non-Indigenous meanings as opposed to Indigenous meanings. The language and beliefs of the Indigenous people Wells obtained her information from, and of the Indigenous perspective she tries to present, conflict with English language and meaning. The author tried to express both her knowledge and the Indigenous 
knowledge she uses, in an often divergent way.

Representations of Indigenality and the exclusion of Indigenous child readers from the subject position of the reader in Australian children's literature were effected by language. What characters say, how they say it, the flow of their thoughts and their responses are all presented according to non-Indigenous literary or social practices. Only recently have such practices and conventions been challenged and dismantled through the use of Aboriginal English and innovative literary techniques. Perhaps Indigenous authors include Indigenous child readers more notably because their representation of Indigenality is less influenced by colonising discourses that, established in the nineteenth-century, have now become traditional and often perpetuate stereotypes and misinterpretations. Representations of Indigenality by non-Indigenous authors have not progressively improved over the past two centuries. Romance and fantasy narratives have attempted to fabricate, accommodate or annihilate Indigenous Australians since colonisation, thus implicitly acknowledging the presence and prior rights of Indigenous peoples.

\section{NOTES}

1. Throughout this essay I have used the word 'Indigenality' rather than 'Aboriginality' to refer to Indigenous peoples and issues. My understanding of the word has stemmed from the work of Mudrooroo, in particular Us Mob. History, Culture, Struggle: An Introduction to Indigenous Australia (Sydney, Angus and Robertson, 1995) and Milli Milli Wangka: The Indigenous LIterature of Australia (Melbourne, Hyland House, 1997).

\section{REFERENCES}

Bhabha, Homi (1994) The Location of Culture. London, Routledge.

Boon, Poppy (1993) The Black Crystal. Melbourne, Longman Cheshire.

Bradford, Clare (2001) Reading Race: Aboriginality in Australian Children's Literature. Carlton South, Melbourne University Press.

Cawelti, John G. (1976) Adventures, Mystery and Romance: Formula Stories as Art and
Popular Culture. Chicago, University of Chicago Press.

Crotty, Martin (2001) Making the Australian Male: Middle-Class Masculinity 1870 - 1920. Carlton South, Melbourne University Press.

Davison, Frank Dalby (1936) Children of the Dark People. Sydney, Angus \& Robertson.

Ferres, Arthur (1887) My Centennial Gift: or, Australian Stories for Children. Sydney, Turner \& Henderson.

Fitzgerald, Mary Anne (1891) King Bungaree's Pyalla and Stories, Illustrative of Manners and Customs that Prevailed Among Australian Aborigines. Sydney, Edwards, Dunlop \& Co.

Fulford, Tim and Kitson, Peter J. (eds.) (1998) Romanticism and Colonialism: Writing \& Empire, 1780 - 1830. New York \& Melbourne, Cambridge University Press.

Goldie, Terry (1989) Fear and Temptation: The Image of the Indigene in Canadian, Australian and New Zealand Literatures. London, McGill-Queen's University Press.

Jameson, Fredric (1975) 'Magical narrative: romance as genre', New Literary History 7 , 1: 137-63.

Jameson, Fredric (1981) The Political Unconscious: Narrative as a Socially Symbolic Act, Ithaca, New York, Cornell University Press.

Kociumbas, Jan (ed.) (1988) Maps, Dreams, History: Race and Representation in Australia. Sydney, Braxus Press.

Low, Gail Ching-Liang. (1996) White Skins/Black Masks: Representation and Colonialism. London, Routledge.

Parker, Kate Langloh (1978) [1896] Australian Legendary Tales. Sydney, The Bodley Head.

Pedley, Ethel (1949) [1899] Dot and the Kangaroo. Sydney, Angus \& Robertson. 
Smith, Glenys (1987) 'Inner reality: the native of fantasy', in Maurice Saxby, (ed) Give Them Wings: The Experience of Children's Literature. South Melbourne, Macmillan.

Swinfen, Ann (1984) In Defence of Fantasy: A Study of the Genre in English and American Literature Since 1945. London, Routledge \& Kegan Paul.

Wells, Ann E. (1959) Tales From Arnhem Land. Sydney, Angus \& Robertson.

Wells, Ann E. (1961) Rain in Arnhem Land. Sydney, Angus \& Robertson.

Wells, Ann E. (1964) Skies of Arnhem Land. Sydney, Angus \& Robertson.

\section{BIOGRAPHICAL NOTE}

Brooke Collins-Gearing is a Kamilaroi woman who obtained her PhD through the University of Newcastle with assistance from the School of Language and Media and the School of Aboriginal Studies. Her teaching and research interests have focused on Australian Indigenous children's literature and the understanding and application of decolonisation theories.

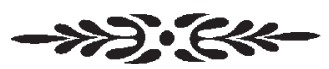

